\title{
Serum concentrations of laminin P1 in diabetics with advanced nephropathy
}

\author{
P PIETSCHMANN, G SCHERNTHANER, C H SCHNACK, S GAUBE \\ From the Department of Medicine II, Division of Metabolism and Endocrinology, University of Vienna, Austria
}

SUMMARY In 97 patients with type I diabetes mellitus, 155 patients with type II diabetes mellitus, and two matched control groups, serum concentrations of laminin P1, a non-collagenous component of basement membranes, were determined by radioimmunoassay to see whether laminin P1 might be a valuable indicator of microangiopathic complications in diabetics. Independent of the type of diabetes, serum laminin concentrations in patients without nephropathy or with early renal damage as assessed by microalbuminuria were comparable with those of the control subjects. Patients with macroproteinuria or with renal insufficiency had significantly increased serum laminin P1 concentrations. Diabetic retinopathy was not found to influence serum laminin P1 concentrations. These data indicate that serum laminin Pl concentrations are increased in advanced diabetic nephropathy.

Basement membranes are structures containing both collagenous and non-collagenous glycoproteins. Laminin, a large non-collagenous glycoprotein component of basement membranes was isolated by Timpl et al. ${ }^{1}$ After digestion with pepsin two distinct antigenic fragments of the protein, laminin $P 1$ and $P 2$, can be isolated. ${ }^{2}$ The morphological feature which characterises diabetic microangiopathy is a thickened capillary basement membrane. ${ }^{3}$ In animal models of diabetes mellitus serum concentrations of basement membrane components such as type IV collagen and laminin were found to be raised. ${ }^{45}$ Thus we investigated whether serum concentrations of the pepsin resistant laminin P1 might be a valuable indicator of microangiopathic complications in diabetic patients.

Accepted for publication 7 April 1988

\section{Patients and methods}

We studied 97 patients with type I diabetes mellitus and 155 patients with type II diabetes mellitus according to the classification of the national diabetes data group. ${ }^{6}$ Clinical characteristics of diabetic patients are shown in the table. Two groups of normal subjects, matched for type I and type II diabetic patients, respectively, served as controls $(n=34$, mean age 33 (2) years and $n=15$, mean age 60 (4), respectively). Types I and II diabetic patients were subdivided as follows: (i) patients without nephropathy (urinary albumin excretion $<15 \mu \mathrm{g} /$ minute); (ii) patients with microalbuminuria (urinary albumin excretion 15-70 $\mu \mathrm{g} /$ minute); (iii) patients with macroproteinuria (urinary protein excretion $>500 \mathrm{mg} / 24$ hours but normal plasma creatinine); (iv) patients with renal in-

Table Clinical characteristics of type I (DM-I) and type II (DM-II) diabetic patients without nephropathy (NP), with microalbuminuria $(M I A)$, with macroproteinuria (MP), and with renal insufficiency (RI) expressed as mean (SEM)

\begin{tabular}{|c|c|c|c|c|c|c|c|c|}
\hline & $\begin{array}{l}\text { DM, } \\
\text { without NP }\end{array}$ & $\begin{array}{l}\text { Dith } M_{I} \\
\text { wIA }\end{array}$ & $\begin{array}{l}\text { DM } \\
\text { with } M P\end{array}$ & ${ }_{\text {with }}^{D M_{1}}$ & $\begin{array}{l}\text { DM } \\
\text { without NP }\end{array}$ & $\begin{array}{l}D M_{\|} \\
\text {with } M I A\end{array}$ & $\begin{array}{l}D M_{\|} \\
\text {with MP }\end{array}$ & $\begin{array}{l}D M_{1 \prime} \\
\text { with } R I\end{array}$ \\
\hline $\begin{array}{l}\text { n } \\
\text { Age (years) } \\
\text { Diabetes duration }\end{array}$ & $\begin{array}{l}53 \\
29\end{array}$ & $\begin{array}{l}25 \\
36(3)\end{array}$ & $\begin{array}{l}13 \\
42(5)\end{array}$ & 39 (6) & $\begin{array}{l}56 \\
64 \text { (1) }\end{array}$ & $\begin{array}{l}68 \\
67 \text { (1) }\end{array}$ & $\begin{array}{l}21 \\
67(2)\end{array}$ & $\begin{array}{l}10 \\
63(2)\end{array}$ \\
\hline $\begin{array}{l}\text { (years) } \\
\text { HbA } \\
\text { Urinary albumin }\end{array}$ & $\begin{array}{l}11(1) \\
7 \cdot 5(0 \cdot 2)\end{array}$ & $\begin{array}{l}14(3) \\
8 \cdot 3(0 \cdot 4)\end{array}$ & $\begin{array}{l}23(3) \\
7 \cdot 9(0 \cdot 5)\end{array}$ & $\begin{array}{l}21(3) \\
8 \cdot 0(0 \cdot 6)\end{array}$ & $\begin{array}{l}10(1) \\
8 \cdot 0(0 \cdot 3)\end{array}$ & $\begin{array}{l}13(1) \\
8 \cdot 4(0 \cdot 3)\end{array}$ & $\begin{array}{l}16(2) \\
9 \cdot 1(0 \cdot 4)\end{array}$ & $\begin{array}{l}17(3) \\
8 \cdot 6(1 \cdot 0)\end{array}$ \\
\hline $\begin{array}{l}\text { excretion }(\mu \mathrm{g} / \mathrm{min}) \\
\text { Urinary protein }\end{array}$ & 7 (1) & $38(4)$ & $126(13)$ & 164 (37) & 7 (1) & 48 (4) & 109 (11) & $114(4)$ \\
\hline $\begin{array}{l}\text { excretion (mg/24h) } \\
\text { Serum creatinine }\end{array}$ & 108 (11) & $110(17)$ & $2526(640)$ & 3865 (798) & $107(11)$ & 171 (12) & 2277 & 2767 (319) \\
\hline$(\mathrm{mg} / \mathrm{dl})$ & $1 \cdot 0(0 \cdot 1)$ & $0.9(0 \cdot 1)$ & $1 \cdot 1(0 \cdot 1)$ & $3.5(0.8)$ & $1 \cdot 0(0 \cdot 1)$ & $1 \cdot 1(0 \cdot 1)$ & $1 \cdot 1(0 \cdot 1)$ & $2 \cdot 6(0 \cdot 3)$ \\
\hline
\end{tabular}


sufficiency (plasma creatinine concentrations of $>1.4$ $\mathrm{mg} / \mathrm{dl})$.

In all diabetic patients and control subjects serum concentrations of the pepsin resistant fragment laminin P1 were measured by a commercial radioimmunoassay (RIAgnost laminin, Behring, Marburg/ Lahn, West Germany).

Intraassay and interassay coefficients of variation were $6.3 \%$ and $6 \cdot 1 \%$, respectively. Plasma creatinine was measured by an American Monitor Parallel Analyser; $\mathrm{HbA}_{\mathrm{lc}}$ by high pressure liquid cromatography (Biorad). The collection period of urinary albumin excretion and urinary protein excretion was 24 hours. Urinary albumin excretion was determined by a commercial radioimmunoassay (Pharmacia, Albumin RIA 100, Uppsala, Sweden). Urinary

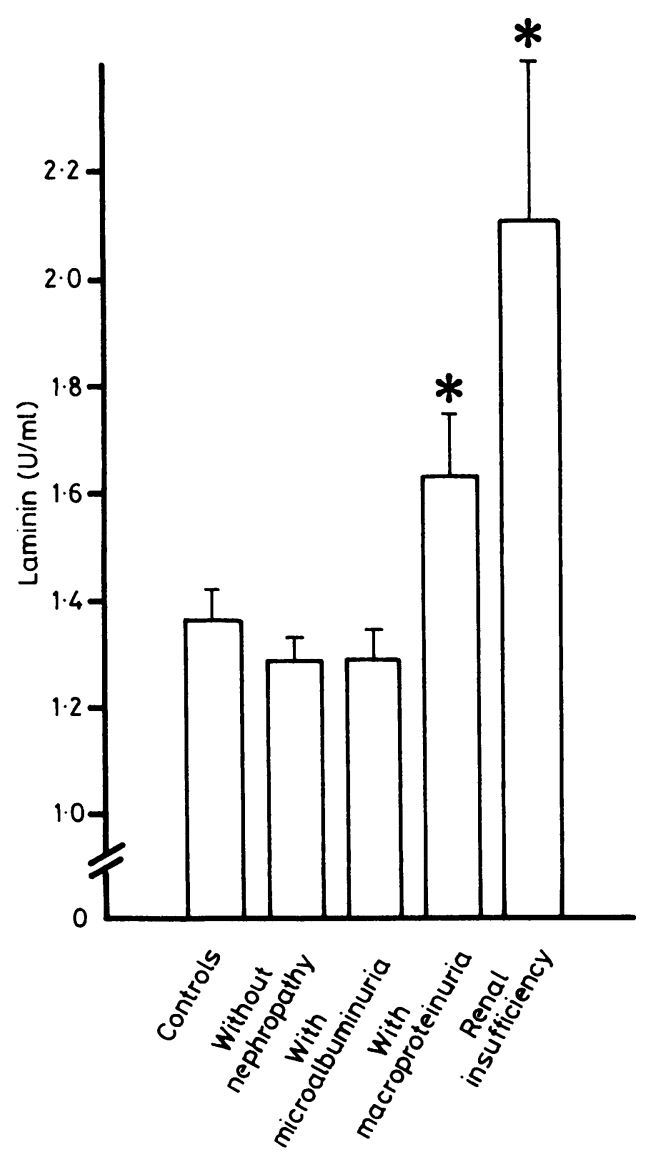

Fig 1 Serum laminin Plconcentrations in control subjects and type I diabetic patients without nephropathy, with microalbuminuria, with macroproteinuria, and with renal insufficiency $(R I)$.

*Indicates significance $v$ control subjects. protein excretion was determined by Biuret reaction.

The presence or absence of diabetic retinopathy was assessed by both fundoscopy and fluorescein angiography.

All the data in the text, the table, and the figures are presented as the mean (SEM) and the $95 \%$ confidence interval $(95 \% \mathrm{CI}){ }^{7}$ Analysis of variance, unpaired Student's $t$ test, and Pearson correlation coefficients were used for statistical evaluation. $P$ values below 0.05 were considered to be significant.

\section{Results}

Figs 1 and 2 show the serum laminin $P 1$ concentrations in diabetic patients and control subjects. Both in types I and II diabetic patients the analysis of variance showed significantly different serum laminin P1 concentrations in the various stages of diabetic nephropathy ( $p<0.0001$ ). Laminin P1 concentrations in type I diabetic patients without nephropathy $(1.29(0.03) \mathrm{U} / \mathrm{ml})$ or with microalbuminuria $(1.29$ $(0.05) \mathrm{U} / \mathrm{ml})$ were not significantly different from those of control subjects $(1.36(0.05) \mathrm{U} / \mathrm{ml} ; 95 \% \mathrm{CI}$ from

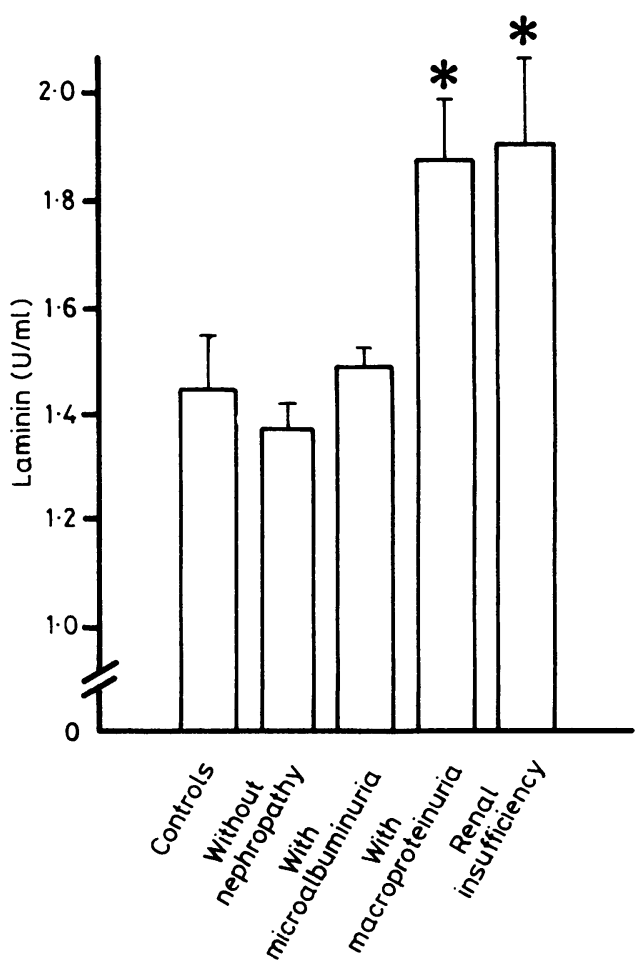

Fig 2 Serum laminin PI concentrations in control subjects and type II diabetic patients without nephropathy, with microalbuminuria, with macroproteinuria, and with renal insufficiency.

*Indicates significance $v$ control subjects. 
-0.18 to $0.04 \mathrm{U} / \mathrm{ml}$ and from -0.21 to $0.07 \mathrm{U} / \mathrm{ml}$, respectively). In contrast, type I diabetic patients with macroproteinuria $(1.63(0.11) \mathrm{U} / \mathrm{ml})$ or with renal insufficiency $(2 \cdot 11(0.29) \mathrm{U} / \mathrm{ml})$ had significantly increased serum laminin concentrations when compared with those of control subjects $(95 \%$ CI from 0.08 to $0.46 \mathrm{U} / \mathrm{ml}$ and from 0.45 to $1.05 \mathrm{U} / \mathrm{ml}$, respectively). Similarly, as in type I diabetic patients, serum laminin concentrations in type II diabetic patients without diabetic nephropathy $(1.37(0.04) \mathrm{U} /$ $\mathrm{ml})$ and with microalbuminuria $(1.49(0.03) \mathrm{U} / \mathrm{ml})$ were comparable with those of the control subjects $(1.45(0.09) \mathrm{U} / \mathrm{ml} ; 95 \%$ CI from -0.27 to $0.11 \mathrm{U} / \mathrm{ml}$ and from -0.13 to $0.21 \mathrm{U} / \mathrm{ml}$, respectively); type II diabetic patients with macroproteinuria $(1 \cdot 88(0 \cdot 10)$ $\mathrm{U} / \mathrm{ml})$ and with renal insufficiency $(1.90(0 \cdot 16) \mathrm{U} / \mathrm{ml})$ had significantly increased serum laminin concentrations $(95 \% \mathrm{CI}$ from $0 \cdot 15$ to $0.71 \mathrm{U} / \mathrm{ml}$ and from 0.12 to $0.78 \mathrm{U} / \mathrm{ml}$, respectively).

Among the patients without diabetic nephropathy serum laminin concentrations were comparable in patients with advanced diabetic retinopathy-type I $(n=8)$ and type II diabetic patients $(n=5)$ and in patients without diabetic retinopathy (10 type I and 13 type II diabetic patients) (in type I diabetic patients: $1.29(0.11) v 1.37(0.11) \mathrm{U} / \mathrm{ml} ; 95 \%$ CI from -0.39 to $0.23 \mathrm{U} / \mathrm{ml})$; in type II diabetic patients: $1.17(0.11) v$ $1 \cdot 19(0.07) \mathrm{U} / \mathrm{ml} ; 95 \%$ CI from -0.28 to $0.24 \mathrm{U} / \mathrm{ml})$.

Both in types I and II diabetic patients a significant positive correlation between serum laminin P1 and serum creatinine concentrations could be found, $(r=0.41 ; p<0.0001$ and $r=0.33 ; p<0.0001$, respectively).

\section{Discussion}

Our data show that serum concentrations of laminin $\mathrm{Pl}$ in type I as well as in type II diabetes mellitus are raised in advanced diabetic nephropathy; serum laminin concentrations in patients without diabetic nephropathy and with microalbuminuria are comparable with those of the control subjects. Serum laminin P1 concentrations were not found to be influenced by the presence or absence of diabetic retinopathy.

Risteli and coworkers studied serum concentrations of the basement membrane components 7-S collagen and laminin P2 in diabetic rats treated with streptozotocin. ${ }^{4}$ Both 7-S collagen and laminin P2 were raised in these rats when compared with non-diabetic control rats. Treatment with insulin prevented the increase of 7-S collagen in the serum but did not completely normalise the laminin P2 concentrations. The authors concluded that the analysis of these antigens in serum may give useful information on the metabolism of basement membranes. Högemann et al reported that serum laminin concentrations in patients with diabetic microvascular lesions were not significantly different from patients without clinical signs of microangiopathy. ${ }^{8}$ The disagreement with our data might be explained by the fact that Högemann et al did not differentiate between patients with retinopathy and nephropathy.

Recently, Karttunen and coworkers' showed that the concentration of laminin in kidney cortex in a diabetic patient with nephropathy was much higher than in the controls, whereas laminin concentrations in kidney cortex of four diabetic patients without signs of nephropathy did not differ from non-diabetic subjects. These data are consistent with our findings of increased serum laminin P1 concentrations in advanced diabetic nephropathy and normal laminin P1 concentrations in patients without diabetic nephropathy. It may be speculated that raised serum laminin concentrations in advanced diabetic nephropathy might reflect an increased synthesis or a disturbed metabolism of basement proteins.

Early detection of diabetic nephropathy seems to have important clinical consequences as recent studies suggest that tight metabolic and blood pressure control might retard progression of incipient diabetic renal damage. ${ }^{10-12}$ Mogensen et al showed that microalbuminuria predicts the development of diabetic nephropathy. ${ }^{13}$ In our study serum laminin P1 concentrations in diabetic patients with microalbuminuria were not increased compared with those of control subjects, indicating that serum laminin P1 concentrations are not a sensitive marker for incipient renal damage. The determination of serum laminin P1 concentrations, however, might be clinically applied as an additional non-invasive variable in studying the clinical course or the effect of therapeutic intervention in advanced diabetic nephropathy.

\section{References}

1 Timpl R, Rohde H. Laminin-a glycoprotein from basement membranes. J Biol Chem 1979;254:9933-7.

2 Rohde H, Bächinger HP, Timpl R. Characterization of pepsin fragments of laminin in a tumor basement membrane. Evidence for the existence of related proteins. $Z$ Physiol Chem 1980;361:1651-60.

3 Williams RH. Textbook of endocrinology 6 th ed. Philadelphia: WB Saunders \& Co, 1981:784.

4 Risteli K, Draeger KE, Regitz G, Neubauer HP. Increase in circulating basement membrane antigens in diabetic rats and effects of insulin treatment. Diabetologia 1982;23:266-9.

5 Hasslacher C, Reichenbacher R, Gechter F, Timpl R. Glomerular basement membrane synthesis and serum concentrations of type IV collagen in streptozotocin-diabetic rats. Diabetologia 1984:26:150-4.

6 National Diabetes Data Group. Classification and diagnosis of diabetes mellitus and other categories of glucose intolerance. Diabetes 1979;28:1039-57.

7 Gardner MJ, Altmann DG. Confidence intervals rather than P 
values: estimation rather than hypothesis testing. $\mathrm{Br}$ Med $\mathrm{J}$ 1986;232:746-50.

8 Högemann B, Voss B, Altenwerth FJ, Schneider M, Rauterberg J, Gerlach $U$. Concentrations of $7 \mathrm{~S}$ collagen and laminin P1 in sera of patients with diabetes mellitus. Klin Wochenschr 1986;64:382-5.

9 Karttunen T, Risteli J, Autio-Harmainen H, Risteli L. Effect of age and diabetes on type IV collagen and laminin in human kidney cortex. Kidney Int 1986;30:586-91.

10 The Kroc Collaborative Study Group. Blood glucose control and the evolution of diabetic retinopathy and albuminuria. $N$ Engl $J$ Med 1984;311:365-72.

11 Viberti GC, Pickup JC, Jarrett RJ, Keen H. Effect of control of blood glucose on urinary excretion of albumin and $B_{2}$ microglobulin in insulin-dependent diabetes. $N$ Engl $\mathrm{J}$ Med 1979;300:638-41.

12 Hommel E, Mathiesen E, Edsberg B, Bahnsen M, Parving HH. Acute reduction of arterial blood pressure reduces urinary albumin excretion in type I (insulin-dependent) diabetic patients with incipient nephropathy. Diabetologia 1986;29:211-5.

13 Mogensen CE, Christensen CK. Predicting diabetic nephropathy in insulin-dependent patients. $N$ Engl J Med 1984;311:89-93.

Requests for reprints to: Professor G Schernthaner, Department of Medicine II, Garnisongasse 13, A-1090 Vienna, Austria.

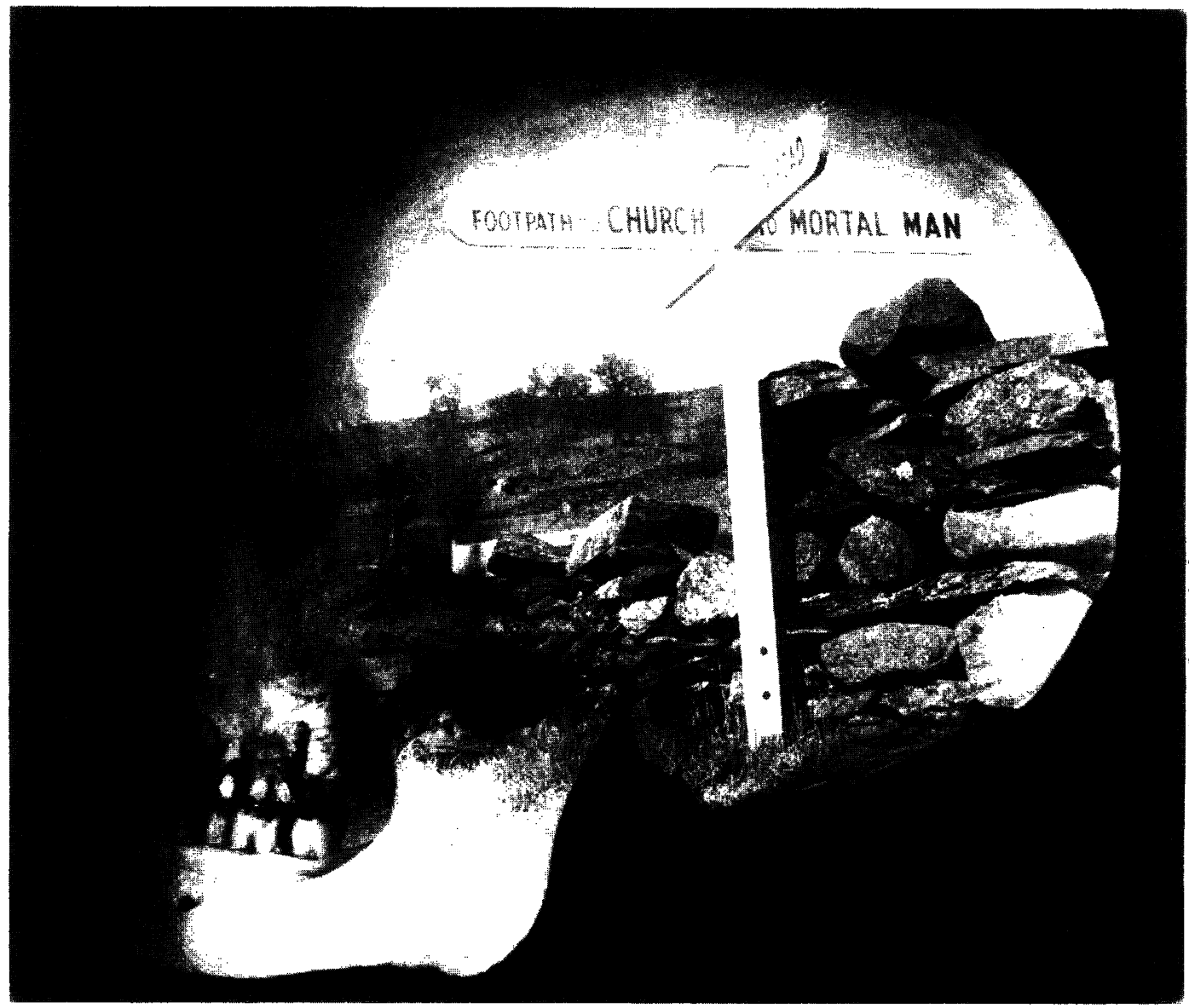

"Sermon at Troutbeck"

P. N. Cowen 